\title{
ANALISIS PENGARUH KONTROL DIRI TERHADAP KECENDERUNGAN PERILAKU SEKSUAL PRANIKAH DITINJAU DARI MAHASISWA
}

\author{
Manara Qudsiya \\ Fakultas Psikologi \\ Universitas Islam Negeri Maulana Malik Ibrahim Malang \\ manaraqudsiya123@gmail.com
}

\begin{abstract}
ABSTRAK: Penelitian bertujuan mengetahui pengaruh tingkat kontrol diri terhadap kecenderungan perilaku seksual pranikah pada mahasiswa. Penelitian menggunakan metode kuantitatif dengan 100 sampel berdasarkan pada purposive sampling. Kontrol diri diukur menggunakan Brief Self-Control Scale dan Reiss Premarital Sexual Permissiveness Scale (Short Form) untuk mengukur perilaku seksual pranikah. Data dianalisis menggunakan product moment. Diperoleh hubungan negatif pada self control terhadap kecenderungan perilaku seksual sebelum menikah pada mahasiwa.

Kata kunci: kecenderungan perilaku seksual pranikah; kontrol diri; mahasiswa
\end{abstract}

ABSTRACT: Research aimed to determine the effect of the level of self control towards the tendency of premarital sexual behavior of student's. The study uses quantitative method with 100 subjects based on purposive sampling. Self control measured by Brief Self-Control Scale and Reiss Premarital Sexual Permissiveness Scale (Short Form) to measure the tendency of premarital sexual behavior. Data were analyzed using product moment. It was found that there was a negative influence on self control toward the tendency of premarital sexual behavior on student's.

Keywords: self control; student; tendency of premarital sexual behavior

\section{PENDAHULUAN}

Saat ini di Indonesia fenomena yang banyak terjadi merupakan perilaku seks bebas yang dilakukan oleh masyarakat. Fakta yang dikutip dari Kompasiana.com, berdasarkan suvei pada tahun 2013 yang dilakukan Komnas Perlindungan Anak (KPAI) di berbagai kota besar di Indonesia didapatkan hasil bahwa sebanyak $62.7 \%$ remaja di Indonesia sudah berhubungan seksual sebelum menikah. Hasil ini berbanding terbalik dengan norma yang ada di Indonesia, yaitu terdapat norma agama, norma susila, dan norma hukum yang diharus diterapkan agar masyarakat dapat hidup teratur. Pada seluruh agama yang ada di Indonesia perilaku seks bebas merupakan hal yang dilarang. Kemudian, mengutip dari Setyawan dkk (2019) bahwa seks bebas tidak terdapat hukum yang tertulis bagi yang melakukan, namun hukum budaya yang menjadi panutan di Indonesia melarang adanya seks bebas bagi seluruh masyarakat. Selain itu, dikutip dari detik.com menurut data survei tahun 2018 yang dilakukan Demografi dan Kesehatan Indonesia (SDKI) pada remaja usia 15 tahun hingga 24 tahun mengungkapkan bahwa terdapat sekitas $2 \%$ remaja wanita dan $8 \%$ remaja pria pernah melakukan hubungan seksual pranikah, bahkan $11 \%$ dari remaja wanita diantaranya mengaku mengalami kehamilan yang tidak diinginkan. Jumlah ini merupakan jumlah yang besar, remaja yang menjadi masa depan bagi negara tidak peduli dengan norma di Indonesia. Dilansir dari Jawapos.com 8 bulan terakhir pada tahun 2018 di Bontang tercatat 17 kasus pernikahan dini dan $60 \%$ diantaranya menikah secara terpaksa karena telah hamil terlebih dahulu. Hasil penelitian Windiarti di Semarang 
mengungkap bahwa perilaku seksual pranikah pada 2009 dari 250 sampel mahasiswa, sebanyak $20,4 \%$ diantaranya mengaku sudah melakukan premarital sexual behavior (Dewi, 2014). Selain itu, aktivitas yang dilakukan saat berkencan adalah $66.8 \%$ kissing, 52\% necking, $29.2 \%$ petting, $25.6 \%$ oral sex, $20.4 \%$ intercourse, dan $6.8 \%$ anal sex. Berdasarkan penelitian Dewi (2014) menunjukkan bahwa sebagian besar hubungan seksual pranikah yang dilakukan subjek dimulai dari perilaku berpacaran.

Kartono dan Gulo (dalam Setiawan dan Nurhidayah, 2008). menjelaskan hubungan seksual sebelum menikah merupakan perilaku yang merangsang reseptor pada organ reproduksi Dalam Kamus Besar Bahasa Indonesia, arti kata nikah adalah ikatan perkawinan yang dilakukan sesuai dengan ketentuan hukum dan agama. Sehingga, perilaku seksual pranikah merupakan segala perilaku yang berdasarkan dorongan seksual untuk mendapatkan kenikmatan dan rangsangan pada bagian reproduksi yang dilakukan antara wanita dengan pria tanpa adanya perjanjian serta ikatan secara resmi sebagai suami istri. Kecenderungan perilaku seksual pranikah dapat dilihat dari cara individu menyikapi perilaku seksual pranikah sendiri. Ketika individu memberikan sikap yang positif terhadap perilaku seksual pranikah, maka dapat diartikan jika individu akan cenderung melakukan perilaku seksual pranikah (Rahardjo $d k k$, 2017). Selanjutnya, Prihatin (2007) menyatakan bahwa para remaja memiliki cara-cara untuk melampiaskan dorongan hubungan seksual pranikah, yaitu pertama, dengan cara bergaul dengan lawan jenis, sehingga dapat menyebabkan remaja melakukan hubungan seksual pranikah. Kedua, menahan diri dengan berbagai cara, hal ini adalah bukti bahwa remaja memiliki kemungkinan untuk menahan dirinya dari dorongan untuk berhubungan seksual misalnya dengan menyibukkan diri dengan berbagai aktivitas yang positif. Remaja yang melakukan hal tersebut merupakan bentuk bahwa remaja tersebut mampu mengontrol dirinya. Ghufron dan Risnawita yang menyatakan kontrol diri merupakan kemampuan seseorang menyesuaikan diri dengan situasi dalam lingkungan dengan cara mengelola faktor perilaku, mengendalikan perilaku, dan mengubah perilaku sehingga sesuai dengan kondisi dan norma (Vitasari, 2016). Menurut Chaplin, self-control diartikan sebagai kemampuan seseorang untuk mengarahkan perilakunya yang implusif, dalam kata lain menekan agar tingkah laku impulsif tidak terjadi (Faried dan Nashori, 2012).

Bersumber dari penelitian terdahulu, dalam penelitian yang dilakukan pada subjek usia remaja antara usia 15 hingga 25 tahun menyatakan bahwa terdapat hubungan negatif antara kontrol diri pada mahasiswa dengan perilaku seksual pranikah. Dapat diartikan bahwa ketika seseorang memiliki self-control yang tinggi, maka kemungkinan munculnya perilaku seksual pranikah akan semakin rendah, begitupun sebaliknya (Dewi, 2014; Khairunnisa, 2013; Noor, 2015). Hal tersebut dikarenakan kontrol diri berhubungan dengan kemampuan individu mengatur dorongan yang muncul, sehingga faktor kontrol diri memiliki pengaruh yang besar terhadap perilaku seksual pranikah. Namun, bertolak dengan hasil penelitian diatas, penelitian Chariri dan Rafiyanti menyatakan hasil bahwa tidak ada pengaruh yang signifikan antara self-control dengan perilaku seksual pranikah dan self-control tidak dapat dijadikan alat untuk memprediksi perilaku seksual pada remaja (Chariri, 2014; Rafiyanti, 2012). Hasil ini disebabkan karena subjek menunjukan hasil kontrol diri yang tinggi, namun kecenderungan subjek melakukan hubungan seksual sebelum menikah juga tinggi. Chariri (2014) dan Rafiyanti (2012) berpendapat bahwa terdapat faktor lain yang bisa menyebabkan subjek melakukan hubungan seks bebas seperti konsep diri dan nilai budaya yang dianut. Ketidak konsistenan hasil yang didapatkan oleh beberapa peneliti menimbulkan pertanyaan besar mengenai pengaruh antara kontrol diri dengan perilaku 
seksual pranikah. Sehingga, kedua hasil berseberangan tersebut menjadi dasar dilakukannya penelitian.

Berdasarkan banyakanya fenomena yang telah terjadi di Indonesia, maka penelitian mengenai pengaruh antara kontrol diri dengan kecenderungan perilaku seksual pranikah pada mahasiswa di rasa perlu. Kontrol diri dalam penelitian ini diartikan sebagai kemampuan subjek dalam mengendalikan, menolak, dan merubah perilakunya terhadap dorongan untuk melakukan perilaku seksual dengan lawan jenisnya sebelum menikah. Sedangkan kecenderungan perilaku seksual pranikah merupakan perilaku seksual antara wanita dan pria yang cenderung dilakukan subjek dan dilakukan sebelum adanya ikatan pernikahan.

Kemudian, peneliti ingin membahas pengaruh self-control terhadap kecenderungan perilaku seksual pranikah terhadap subjek mahasiswa di Universitas Islam Negeri Malang. Selain itu, judul tersebut dipilih karena peneliti ingin menguji kembali hasil yang tidak konsisten dari kedua hasil penelitian terdahulu. Sehingga, tujuan dilakukannya penelitian untuk mengetahui manakah hasil yang terbukti dari kedua hasil penelitian yang berbanding terbalik tersebut. Berdasarkan pemaparan diatas, maka hipotesis yang dikembangkan bahwa terdapat hubungan negatif antara self-control dengan kecenderungan perilaku seksual pranikah.

\section{METODE}

\section{Identifikasi Variabel}

Variabel kontrol diri sebagai variabel bebas merupakan variabel yang digunakan dalam penelitian ini. Selanjutnya, variabel yang menjadi variabel terikat merupakan kecenderungan perilaku seksual pranikah.

\section{Subjek Penelitian}

Dalam penelitian ini, mahasiswa Universitas Islam Negeri Maulana Malik Ibrahim Malang dengan usia 17 hingga 21 tahun merupakan populasi dalam penelitian.
Alasan pemilihan populasi disebabkan oleh akses perolehan data dan subjek penelitian. Karena jumlah populasi yang tidak diketahui, maka diperoleh jumlah sampel dalam penelitian yaitu 100 subjek berdasarkan ketetapan dengan jumlah 23 mahasiswa dan 77 mahasiswi. Kemudian, terdapat 4 subjek dengan usia 17 tahun, 17 subjek dengan usia 18 tahun, 29 subjek dengan usia 19 tahun, 37 subjek dengan usia 20 tahun, dan 13 subjek dengan usia 21 tahun. Seluruh subjek merupakan mahasiswa Universitas Islam Negeri Maulana Malik Ibrahim Malang semester 1 hingga semester 5. Kemudian, pengambilan sampel menggunakan teknik purposive sampling, sehingga pembagian skala dilakukan dengan membagikan skala kepada subjek yang telah memenuhi kriteria penelitian.

\section{Instrumen Penelitian}

Brief Self-Control Scale

Pengukuran kontrol diri dilakukan dengan skala likert yang disusun oleh Tangney, Baumeister, dan Boone adalah Brief Self-Control Scale (BSCS) yang berisikan 9 item. Menurut analisis alpha cronbach skala memiliki nilai $\alpha=0,747$ yang artinya BSCS merupakan skala yang akan memberikan hasil tetap pada subjek yang sama. Berdasarkan 9 item tersebut, terdapat 6 item yang valid. Hasil perhitungan validitas menunjukkan angka korelasi setiap item yang valid yaitu rix $=0,448-0,510$ pada skala ini sehingga ditemukan 5 item aspek impulsivitas dan 1 item aspek pengendalian yang valid. Hal ini disebabkan 6 item yang valid karena syarat besar angka korelasi terpenuhi yaitu diatas 0,3. Maka, 3 item yang berasal dari aspek pengendalian yaitu pada item nomor 1,4 , dan 5 gugur karena tidak memenuhi syarat angka korelasi.

Reiss Premarital Sexual Permissiveness Scale Variabel kecenderungan perilaku seksual pranikah diukur menggunakan skala likert yaitu Reiss Premarital Sexual Permissiveness Scale (Short Form) yang disusun oleh Reiss. Terdapat 4 item yang 
terdiri dari dua aspek yaitu aspek permissiveness with affection dan aspek permissiveness without affection. Melalui analisis alpha cronbach didapatkan nilai $\alpha=$ 0,922 , sehingga RSPS merupakan skala yang akan menghasilkan hasil yang sama walaupun digunakan beberapa kali pada subjek yang sama. Hasil perhitungan validitas menunjukkan bahwa 4 item keseluruhan dalam reiss premarital sexual permissiveness scale (short form) merupakan item yang valid dengan rix $=0,788-0,886$ karena karena syarat besar angka korelasi dari seluruh item terpenuhi yaitu diatas 0,3 .

\section{Teknik Analisis Data}

Teknik analisa product moment digunakan untuk mengolah data hasil penelitian dengan alat bantu SPSS. Teknik ini digunakan dengan tujuan untuk melihat pengaruh antara variabel dependen dengan variabel independen dalam penelitian.

\section{HASIL}

Hipotesis penelitian yang dikembangkan memprediksi bahwa kontrol diri berkorelasi negatif dengan kecenderungan perilaku seksual pranikah. Uji korelasi tabel 1 menunjukkan bahwa terdapat pengaruh negatif yang signifikan antara variabel self-control dengan variabel kecenderungan perilaku seksual pranikah $(r=$ $-0,283, p<0,05)$. Hal ini berarti, apabila subjek mampu untuk mengontrol perilaku yang didorong oleh dorongan seksual, maka kecenderungan subjek melakukan perilaku seks pranikah akan menurun.

Tabel 1 Intercorrelation between Self-Control Variable and Tendency

Premarital Sexual Behavior Variable

\begin{tabular}{|c|c|c|c|c|c|c|c|}
\hline & & 1 & 2 & 3 & 4 & 5 & 6 \\
\hline 1 & Kontrol diri & 1 & $-.283 * *$ & $.982 * *$ & $.660 * *$ & $-.305 * *$ & $-.224 *$ \\
\hline 2 & $\begin{array}{l}\text { Perilaku seksual } \\
\text { pranikah }\end{array}$ & & 1 & $-.291 * *$ & -.133 & $.974 * *$ & $.945 * *$ \\
\hline 3 & Impulsivitas & & & 1 & $.508^{* *}$ & $-.304 * *$ & $-.245^{*}$ \\
\hline 4 & Pengendalian & & & & 1 & -.185 & -.045 \\
\hline 5 & $\begin{array}{l}\text { Permissiveness } \\
\text { with affection }\end{array}$ & & & & & 1 & $.847 * *$ \\
\hline 6 & $\begin{array}{l}\text { Permissinevess } \\
\text { without affection }\end{array}$ & & & & & & 1 \\
\hline
\end{tabular}

Keterangan: ${ }^{* *} p<0,001 ; * p<0,05$

Selanjutnya, berdasarkan data aspek pengendalian (restraint) memiliki kontribusi yang kurang dominan terhadap variabel kontrol diri dengan $r=0,660$ dibandingkan dengan kontribusi aspek impulsivitas dengan $r=0,982$. Namun, aspek pengendalian tetap memiliki hubungan dan keterpengaruhan yang signifikan terhadap kontrol diri dengan $p$ yang sama besar dengan aspek impulsivitas yaitu 0,000 .
Berdasarkan analisis product moment walaupun aspek pengendalian memiliki keterpengaruhan terhadap variabel kontrol diri, namun aspek pengendalian dari variabel kontrol diri tidak berpengaruh pada variabel kecenderungan perilaku seksual pranikah. Selain itu, hasil yang sama terjadi pada kedua aspek variabel kecenderungan perilaku seksual pranikah terhadap aspek pengendalian dimana tidak terdapat 
signifikansi diantara keduanya. Hal ini dapat disebabkan karena aspek pengendalian pada skala yang digunakan hanya terdapat satu item yang valid, sehingga jumlah item pada aspek impulsivitas dan aspek pengendalian kurang seimbang dan berakibat pada perhitungan yang kurang setara.

Kemudian, pada variabel terikat yaitu kecenderungan perilaku seksual pranikah besar nilai $r$ pada setiap aspek hampir setara, yaitu 0,974 untuk aspek permissiveness with affection dan 0,945 untuk aspek permissiveness without affection. Hal ini berarti kedua aspek kecenderungan perilaku seksual pranikah memiliki kontribusi yang sama besarnya terhadap variabel kecenderungan perilaku seksual pranikah. Kemudian, aspek permissiveness with affection dan aspek permissiveness without affection juga memiliki pengaruh yang negatif terhadap aspek impulsivitas pada variabel kontrol diri. Sehingga, ketika subjek tidak setuju terhadap segala bentuk hubungan seksual pranikah, hal tersebut disebabkan kemampuan subjek dalam mencegah perasaan spontan yang impulsif.

Setelah dilakukan analisis deskripsi terhadap data, maka didapatkan hasil bahwa pada variabel kontrol diri dari keseluruhan subjek berjumlah 100 subjek, didominasi pada kategori yang sedang. Terdapat 3 subjek yang berada pada tingkatan selfcontrol rendah dan 26 subjek dengan tingkatan self-control yang tinggi. Kemudian, sebanyak $71 \%$ dari subjek penelitian atau sebanyak 71 subjek berada pada tingkatan self-control yang sedang. Hal ini menunjukkan bahwa secara deskripsi subjek umumnya memiliki self-control yang redang. Hal ini dapat mengindikasikan subjek cenderung mampu dalam mengontrol perilaku impulsif yang berasal dari dorongan seksual yang muncul.

Selanjutnya, pada variabel kecenderungan perilaku seksual pranikah hasil menunjukkan bahwa sebanyak $8 \%$ subjek memberikan tanggapan positif terhadap perilaku seksual pranikah, artinya subjek memiliki kecenderungan melakukan perilaku seksual pranikah yang tinggi. Terdapat 4\% subjek yang kecenderungan perilaku seksual pranikahnya berada pada taraf sedang. Jumlah tertinggi berada pada kecenderungan perilaku seksual pranikah dengan tingkatan rendah, subjek penelitian sebesar $88 \%$ bersikap negatif terhadap premarital sexual behavior baik pada aspek permissiveness with affection dan aspek permissiveness without affection. Sehingga, dapat diartikan bahwa subjek cenderung berhati-hati dalam menentukan ekspresi atau tindakan yang berkaitan dengan seksualitas.

\section{PEMBAHASAN}

Berdasar pada hasil penelitian dan analisis data secara umum ditemukan bahwa terdapat pengaruh yang negatif antara selfcontrol dengan kecenderungan perilaku seksual pranikah, yang berarti apabila individu memiliki kontrol diri yang tinggi, maka kecenderungan subjek melakukan perilaku seksual pranikah akan semakin rendah. Hasil menunjukan kesesuaian dengan hipotesis yang telah disampaikan dan sesuai dengan penelitian terdahulu yang dilakukan oleh Dewi (2014), Kairunnisa (2013), dan Noor (2015). Berarti, hasil tidak susuai dengan penelitian terdahulu oleh Chariri (2014) dan Rafiyanti (2012). Namun, setelah dilakukan analisis data secara mendalam hasil penelitian menunjukan kecenderungan tingkat kontrol diri subjek berada pada tingkat sedang dan tingkat kecenderungan perilaku seksual pranikah berada pada tingkat rendah. Jawaban ini dianggap sesuai karena pada skala kontrol diri peneliti memberikan pilihan jawaban "bisa jadi" dan sebagian besar subjek memilih jawaban tersebut pada beberapa item yang dapat memengaruhi hasil tingkatan dari hal yang akan diukur untuk berada pada tingkat sedang. Selain itu, faktor lain juga bisa mempengaruhi hasil penelitian menjadi unik pada subjek yang memiliki karakteristik memiliki agama yang sama yaitu agama Islam karena subjek 
merupakan mahasiswa Universitas Islam Negeri yang seluruh mahasiswanya beragama Islam. Menurut Andisti dan Ritandiyono bahwa religiusitas dapat mempengaruhi kecenderungan seseorang untuk melakukan hubungan seksual sebelum menikah karena apabila seseorang memiliki tingkat religiusitas yang tinggi ia bertujuan kepada Tuhan, sehingga ia akan berusaha untuk menerapkan ajaran dalam agamanya pada perilaku sehari-hari (Tristiadi, 2016). Maka, dorongan seksual yang muncul tidak dapat menyerang tembok religiusitas yang dimiliki. Berdasarkan hasil yang menunjukkan self-control pada subjek sedang tetapi kecenderungan perilaku seksual rendah. Beragam faktor dapat mempengaruhi hasil penelitian salah satunya karena faktor religiusitas dari subjek. Hal ini dapat diprediksi subjek dapat memiliki kategori yang tinggi pada variabel lain yang seharusnya membutuhkan kontrol diri yang tinggi. Misalnya, terdapat kemungkinan yang yang besar apabila tingkat kontrol diri subjek yang sedang ketika dihadapkan pada kemalasan belajar, subjek akan memiliki tingkat kemalasan belajar yang sedang pula atau bahkan tingkat kemalasan belajarnya tinggi. Selain itu, apabila aspek religiusitas berpengaruh pada tingkat kecenderungan perilaku seks sebelum menikah. Maka, dapat diprediksi ketika subjek dihadapkan pada situasi yang mendorong untuk berhubungan seks pranikah, subjek cenderung tidak melakukan perilaku tersebut walaupun kemampuan kontrol dirinya tidak maksimal.

Berdasarkan teori, dari hasil analisis deskripsi menunjukkan bahwa subjek penelitian memiliki tingkat kontrol diri yang sedang. Hal tersebut menunjukan bahwa subjek sudah mampu untuk mengarahkan, mengendalikan, sekaligus mengubah kecenderungan perilaku seksual pranikah yang kurang sejalan dengan norma yang berlaku (Vitasari, 2016; Faried dan Nashori, 2012). Sesuai dengan aspek pada skala kontrol diri, pertama impulsivitas artinya subjek mampu untuk mengontrol pikiran dan perasaan spontan tentang perilaku yang impulsif sehingga tidak terealisasikan pada perilaku. Misalnya, ketika keinginan spontan subjek untuk berhubungan seksual dengan lawan jenis muncul subjek tidak sekaligus melakukan pikiran impulsifnya namun subjek sudah mampu mengendalikan hal tersebut. Aspek yang kedua merupakan aspek pengendalian, menurut aspek pengendalian subjek telah mampu untuk mendisiplinkan dirinya sendiri dan mengendalikan godaan yang bersifat negatif baik dari eksternal maupun internal. Namun pada hasil penelitian ini, aspek pengendalian tidak berpengaruh terhadap dorongan untuk berhubungan seksual sebelum menikah.

Kemudian, hasil analisis deskripsi variabel kontrol diri yaitu kecenderungan berperilaku seksual pranikah berada pada tingkatan yang rendah pada sikap subjek terhadap perilaku seksual pranikah. Maksudnya, ketika subjek memiliki skor yang rendah pada skala sikap terhadap perilaku seksual pranikah maka kecenderungan subjek untuk melakukan perilaku seksual pranikah akan semakin kecil. Hasil penelitian sesuai dengan teori Raharjo dkk (2017) yaitu subjek memiliki kecenderungan perilaku seksual sebelum menikah yang rendah karena sebagian besar subjek menyatakan tidak setuju terhadap segala bentuk perilaku seksual sebelum adanya ikatan pernikahan. Pengukuran variabel kontrol diri meliputi dua aspek. Pertama, permissiveness with affection yaitu aspek yang berhubungan dengan hubungan seksual sebelum menikah yang dilakukan dengan rasa cinta yang besar menujukkan hasil bahwa subjek memberikan sikap yang negatif. Artinya, walaupun kedua belah pihak memiliki rasa cinta dan kasih sayang kuat antara satu dengan yang lainnya subjek tetap tidak setuju apabila hubungan seksual dilakukan sebelum adanya pernikahan. Kemudian, aspek permissiveness without affection didefinisikan sebagai hubungan seksual sebelum menikah tanpa adanya rasa cinta, tetapi terdapat ketertarikan fisik. Pada 
aspek berikut subjek menunjukkan respon negatif pula. Hal ini dapat dimaknai bahwa subjek tidak setuju pula terhadap hubungan seksual yang dilakukan sebelum adanya pernikahan antara kedua belah pihak.

Setelah dilakukan penelitian pada variabel kontrol diri terhadap variabel kecenderungan perilaku seks pranikah pada subjek mahasiswa didapatkan hasil yang sesuai dengan penelitian terdahulu, namun kondisi subjek berbeda. Hal tersebut bisa terjadi dikarenakan perbedaan skala yang digunakan dan perbedaan kondisi, agama, dan budaya yang dianut oleh subjek. Selain itu, terdapat beberapa kendala dalam penelitian ini yaitu keterbatasan skala yang diaplikasikan, sehingga menyebabkan salah satu aspek tidak signifikan terhadap variabel bebas yang digunakan, dan keterbatasan pembahasan terhadap pengaruh penyebab lain terhadap hasil penelitian.

\section{KESIMPULAN}

Berdasarkan hasil penelitian dan analisis data maka didapatkan kesimpulan bahwa hipotesis penelitian diterima. Hal tersebut disebabkan hasil penelitian mengungkapan adanya hubungan negatif antara self-control terhadap kecenderungan perilaku premarital sexual. Namun, disebabkan adanya faktor lain yang mempengaruhi hasil penelitian seperti religiusitas subjek dan kecenderungan subjek menjawab pilihan jawaban "bisa jadi" sehingga, dalam kategorisasi menunjukkan bahwa subjek memiliki tingkat kontrol diri yang sedang dan tingkat kecenderungan perilaku seksual pranikah yang rendah. Maka, dapat diartikan jika kondisi subjek memiliki kontrol diri yang sedang dan kecenderungan perilaku seksual pranikahnya akan rendah.

\section{REKOMENDASI}

Kepada peneliti selanjutnya diharapkan dapat menggunakan skala yang lebiih akurat dan memperluas pembahasan terhadap faktor lain yang dapat mempengaruhi kecenderungan perilaku seksual sebelum adanya ikatan pernikahan. Hal ini agar hasil penelitian lebih jelas dan dapat dijelaskan dari berbagai sudut pandang yang berbeda. Selain itu, bagi subjek penelitian diharapkan lebih mewaspadai dan menjaga diri sendiri dari perilaku seksual sebelum adanya ikatan pernikahan. Selanjutnya, subjek diharakan dapat meningkatkan tingkat kontrol diri terhadap segala aspek dalam kehidupan. sehingga, terbentuk keteraturan dan terhindar dari perilaku yang negatif atau maladaptif yang dapat memberikan dampak buruk bagi subjek itu sendiri dan orang lain.

\section{DAFTAR RUJUKAN}

Chariri, A.F. 2014. Pengaruh Kontrol Diri Terhadap Perilaku Seksualitas Mahasiswa Universitas Pembangunan Nasional 'Veteran" Fakultas Ilmu Sosial Jurusan Administrasi Bisnis Angkatan 2011 Surabaya. Skripsi tidak dipublikasikan, Malang.

Dewi, A.K. 2014. Hubungan Kontrol Diri dengan Perilaku Seksual Pranikah pada Mahasiswa Universitas Negeri Semarang. Developmental and Clinical Psychology. Vol. 3. No 1. 1317.

Faried, L. dan Nashori, F. 2012. Hubungan antara Kontrol Diri dan Kecemasan Menghadapi Masa Pembebasan pada Narapidana di Lembaga Pemasyarakatan Wirogunan Yogyakarta. Khazanah. Vol. 5. No 2. 63-74.

Istiqomah, N. dan Notobroto, H.B. 2016. Pengaruh Pengetahuan, Kontrol Diri, terhadap Perilaku Seksual Pranikah di Kalangan Remaja SMK di Surabaya. Jurnal Biometrika dan Kependudukan. Vol. 5. No 2. 125-134. 


\section{PSIKOVIDYA}

Vol 24, No. 1, April 2020

Khairunnisa, A. 2013. Hubungan Religiusitas dan Kontrol Diri dengan Perilaku Seksual Pranikah Remaja di MAN 1 Samarinda. eJournal Psikologi. Vol. 1. No 2. 220-229.

Mahyarni. 2013. Theory of Reasoned Action dan Theory of Planned Behavior (Sebuah Kajian Historis Perilaku). Jurnal El-Riyasah. Vol. 4. No 1. 1323.

Noor, R. 2015. Hubungan Antara Kontrol Diri dengan Perilaku Seksual Remaja pada Siswa SMK Istiqomah Muhammadiyah 4 Samarinda. Skripsi tidak dipublikasikan, Surabaya.

Prihatin, T.W. 2007. Analisis Faktor-Faktor yang Berhubungan dengan Sikap Siswa SMA Terhadap Hubungan Seksual (Intercourse) di Kota Sukoharjo Tahun 2007. Tesis tidak dipublikasikan, Semarang.

Rafiyanti, R. 2012. Hubungan Antara Kontrol Diri dengan Perilaku Seksual Pranikah pada Mahasiswa. Skripsi tidak dipublikasikan, Surakarta.

Rahardjo, W., Citra, A.F., Saputra, M., Damariyanti, M., Ayuningsih, A,M., dan Siahay, M.M. 2017. Perilaku Seks Pranikah pada Mahasiswa: Menilik Peran Harga Diri, Komitmen Hubungan, dan Sikap terhadap Perilaku Seks Pranikah. Jurnal Psikologi. Vol. 44. No 2. 139-152.

Setiawan, R. dan Nurhidayah, S. 2008. Pengaruh Pacaran terhadap Perilaku Seks Pranikah. SOUL: Jurnal Ilmiah Psikologi. Vol. 1. No 2. 59-72.

Setyawan, S.A., Gustaf, M.A.M., Pambudi, E.D., Fatkhurrozi, M., dan Anwar, S. 2019. Pergaulan Bebas di Kalangan Mahasiswa dalam Tinjauan Kriminologi dan Hukum. Seminar
Nasional Hukum Universitas Semarang. Vol. 5. No 2. 163-186.

Suharyat, Y. 2009. Hubungan antara Sikap, Minat, dan Perilaku Manusia. Jurnal FKIP: Region. Vol. 2. No 1. 1-19.

Tristiadi, F.A. 2016. Faktor-faktor yang Berhubungan dengan Perilaku Seksual Pranikah pada Mahasiswa Program Studi Ilmu Keperawatan Universitas Muhammadiyah Yogyakarta. Tesis tidak dipublikasikan, Yogyakarta.

Vitasari, I. 2016. Kejenuhan Belajar Ditinjau dari Kesepian dan Kontrol Diri Siswa Kelas XI SMAN 9 Yogyakarta. Skripsi tidak dipublikasikan, Yogyakarta.

Wahdah, N.I. 2016. Hubungan Kontrol Diri dan Pengungkapan Diri dengan Intensitas Penggunaan Facebook pada Siswa SMP Sunan Giri Malang. Tesis tidak dipublikasikan, Malang. 